\title{
Research on Objects of the Geography of Education
}

\author{
Saidong Lv,", Yujun Pan ${ }^{1,2}$, Mingdong Luo ${ }^{3}$, and John Buchanan ${ }^{4}$ \\ ${ }^{1}$ School of Tourism and Geographical Sciences, Yunnan Normal University, Kunming, 650500, \\ China \\ ${ }^{2}$ Key Laboratory of Education Informatization for Nationalities of Ministry of Education, Kunming, \\ 650500, China \\ ${ }^{3}$ Chuxiong Normal University, Chuxiong, 675000, China \\ ${ }^{4}$ University of Technology Sydney, Sydney, 2007, Australia \\ *Corresponding author: lvsaidong@163.com
}

Keywords: Geography of education, spatial structure, temporal structure

\begin{abstract}
Geography of education is an interdisciplinary subject between education and geography. Although the related research of geography of education started earlier, the development of the entire discipline is relatively slow. In recent years, more and more domestic and foreign scholars have realized that the influence of geographical factors on education is objective and its role is enormous. Therefore, many scholars began to research in geography of education, which played a role in promoting its development. In the process of reading a large number of documents, it was found that most scholars emphasized that "space", "time" and "scale" are some key points that cannot be ignored in the research of geography of education. On the basis of summarizing previous researches on geography of education, it is recognized that the research object of Geography of Education is the basis of theoretical research and empirical research of it. From the perspective of the research object of geography of education, this article clearly defines the significance and value of the research object of geography of education, discusses the connection and synergy between two different disciplines of geography and education, and sorts out different views of different scholars at home and abroad on geography of education. Finally, it is concluded that the research object of geography of education is the educational geographic complex and its spatial structure and temporal structure are systematically elaborated.
\end{abstract}

\section{Introduction}

All the scientific unity is found in geography, and the significance of geography lies in its use of the Earth as an eternal home for human ${ }^{[1]}$. Geography has attributes that span the natural and social sciences $^{[2]}$, while education is both a phenomenon and a field of research ${ }^{[3]}$.Although education plays a central role in national construction, economic development, reproduction and cultural, political and social affairs, it has always been on the verge of geography ${ }^{[4]}$.

The research of geography of education as a crossover research of geography and education emerged in the middle of the 20th century. The research of early education geography mainly aims at solving the spatial problems of education with the aid of geography perspectives and tools, 
including educational planning, educational land use, school choice, and educational opportunities and results related to the place of residence. As an interdisciplinary new discipline, geography of education involves a wider range of social sciences. This is because the spatial turn in these disciplines encourages interest in the field of education and learning ${ }^{[5]}$. In the context of considering different cultural backgrounds and educational global landscape, the new discipline of geography of education should be given more opportunities for development ${ }^{[6]}$. Geography of education takes the spatial distribution of education as the centerpiece of its research, and discusses the geographical distribution, changes, diffusion patterns and geographical types of educational activities and their relationship with geographical environment in order to provide basis for education management, education decision-making planning, and educational activities. Although geography of education is a new discipline, the absolute age and relative age are relatively young and the maturity is poor, it has special research objects. Because, having a unique research object is a fundamental symbol that distinguishes a discipline from others ${ }^{[7]}$. Decades ago, scholars discovered that geography of education only had fragmented, sporadic, isolated documents, but now people are increasingly interested in geography of education.

The research of early and narrow achievements has been extended to such topics as school selection, international student migration, education industry, knowledge economy formation, and lifelong learning ${ }^{[8,9,10]}$. To clarify the position of geography in the modern disciplinary system and the research object of geography science is the basis and prerequisite for understanding and the development of geography science ${ }^{[11]}$. As a sub-discipline of geography, it is of course imperative to clarify the research object of geography of education.

\section{Synergic relationship between geography and education}

Our understanding of the world is always from a certain point of view, or somewhere. We see from here, not from there. We use geography to describe a series of interactions about how educational practice passes through space or as a phenomenon in space ${ }^{[12]}$. Geography and education are comprehensive subjects ${ }^{[13]}$. British geography Professor Brock pointed out that the synergic relationship between geography, comparative education and geography of education are mainly "information flow",[14].

Wherever this information flow occurs, it includes everything that happens in the classroom, in the lecture hall, through books, radio, or television and the Internet, etc. At the same time, Prof. Brock illustrated the two different comprehensive disciplines of geography and education with charts. See Figure 1 and Figure 2 for details. From Figures 1 and 2, it can be seen that Prof. Brock listed geography of education as a sub-discipline in the discipline of education, and in the research field of geography, geography of education belongs to the category of human geography. At the same time, it can be seen from the chart that education and geography have certain synergic relationship. We have to admit that the potential for the development of geography of education in education and geography is enormous. 


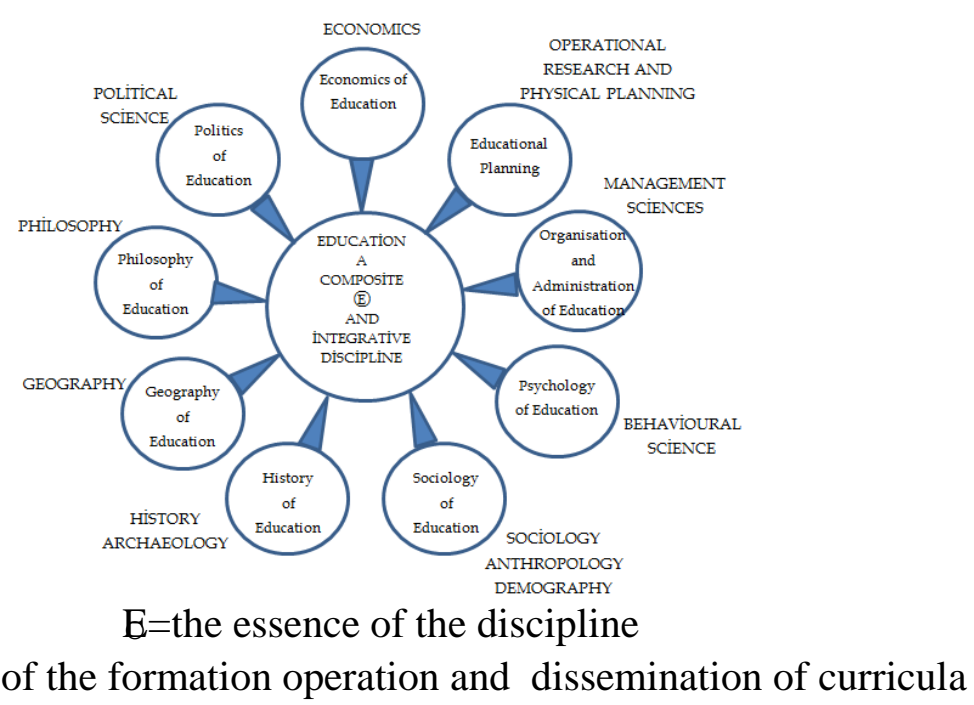

Fig.1. Education: A composite and integrative discipline

Source: Brock, C.(1992), The Case for a educational geography, PHD Thesis, University of Hull,

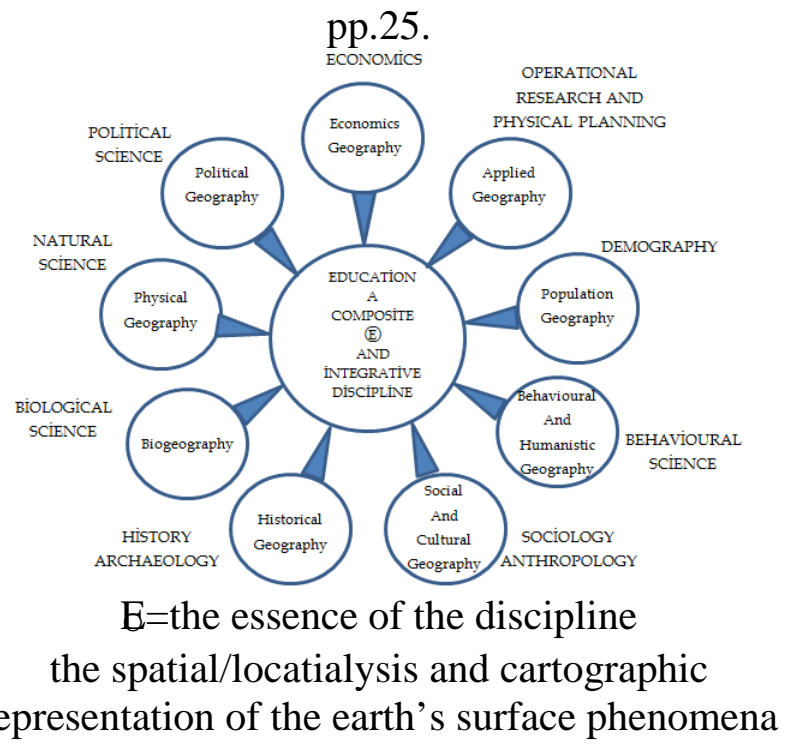

Fig.2. Geography: A composite and integrative discipline

Source: Brock, C.(1992), The Case for a educational geography, PHD Thesis, University of Hull, pp.33.

\section{Significance of research object of geography of education}

The most basic element for the establishment of a discipline is the research object. Whether or not it has a unique research object is the fundamental symbol for determining whether a discipline can be established. Geography of educational is a typical cross-discipline. If you break away from the basics of geography to explore education or break away from education to discuss geography, this will no longer be the content and object that geography of education should research. What are the characteristics of interdisciplinary? The main thing is that the law of movement of objects in research objects or research objects is dominated by two major types of nature factors at the same time. Education is produced, developed, and carried out in a certain extent in human social life, material production methods and geographical environment. It has strong regional characteristics. 
The geographical environment is different, which forms the regional differences and characteristics of different countries and regions in the historical evolution, distribution changes and spatial structure of education. The regional reflections and laws of educational differences and characteristics constitute an independent contradictory movement within human geography that is different from other geographical phenomena, thus constituting a unique research object and research content of geography of education ${ }^{[15]}$. The research object of geography of education is the starting point for the research of geography of education; it is the basis for determining the content, research methods, disciplinary system, and the core of research in geography of education; it is one of the most basic elements of the distinction between geography of education and other disciplines.

\section{Different understanding of domestic scholars on the research object of geography of education}

\subsection{Professor Luo Mingdong's point of view}

Professor Luo is the first person who systematically discusses and studies the discipline of "geography of education" in China, and also profoundly expounds the research object of geography of education. The relationship between education and geographical environment is not only a core issue in the research of geography of education, but also a major basic educational issue. Education is not simply, flatly subject to the constraints of certain social politics, economy, culture and productivity, nor is it simply counteracting these social factors. Education is also directly or indirectly influenced by the geographical environment, and this influence is deep and dynamic ${ }^{[15]}$. At the same time, Prof. Luo also explained the object of geography of education from the aspects of education's geography or special stipulation of issues, geography of education and diversity, and finally stated: although geography of education studies educational phenomena or educational issues in the same way as other educational disciplines, it only studies geographically significant educational phenomena or educational problems, or it only studies geography aspects of educational phenomena or educational issues ${ }^{[7]}$.

\subsection{Professor Pan Yujun's point of view}

Professor Pan gives a full and detailed explanation of the subject of geographical science research in his book Introduction to Geographical Science. It mainly discusses the existing knowledge and basic understanding of geographic scientific research objects, the boundary and structure of terrestrial space systems on the Earth's surface, and the understanding process. And he points out that we should follow the highest principle of Marxism on theoretical innovation - the unity of history and logic, From the perspective of the "unity of history and logic" and its historical and logical perspective, it is finally concluded that the object of research in geography science is the "surface system of Earth's land surface" ${ }^{\text {, } 16]}$. Professor Pan's systematic exposition of the research object of geography of education is in the book research on Geographical Planning of Education. He clearly points out that geography of education is one of the subdisciplines of geography. According to the logic principle from general to concrete deduction, the research object and core of geography of education are the objectification and specialization. The research object of geography of education is the educational space system of the Earth's land surface, and it has regional features including scale regional characteristics and type regional characteristics. 


\subsection{Professor Yi Jidong's point of view}

Professor Yi systematically expounds the research object of geography of education in the article Thoughts on the Object and Content of geography of education: "The research of geography of education is based on the research of many elements of education in terms of elements, and is based on the elemental system of educational issues and educational phenomena. Education is based on educational phenomena and education issues, sums up the scientific theories and practices of human education activities, explores and solves practical education problems encountered in the process of the generation and development of educational activities, and thus revealing the general laws of education. The study of geography of education is in the form of a geographical system of geography. The research object of geography of education is closely related to the structural system of education and the geographical system of geography"[17].

\subsection{Other scholars' point of views}

Geography of education focuses on the relationship between educational events and geographical environment within a certain area, including the geographical system and spatial distribution of educational events. Therefore, Chinese geography of education is an emerging discipline that studies the relationship between the geographical context of education in China and its geographical environment ${ }^{[18]}$. Geography of education is the science of studying the formation, development and layout of the regional education industry and its geographical combination. The research object of geography of education should reflect two core contents: space and environment. Space and environmental issues are the background for the development of modern geography science, and they are also issues that need to be resolved urgently in the development of society. Therefore, geography of education is a discipline that studies the spatial distribution of educational phenomena and its development and changes, and reveals the relationship between educational activities and geographical environment ${ }^{[19]}$. The research object of geography of education is "Education Geographical Phenomenon", which is the geographic phenomenon of educational activities. It mainly includes geography of education problems, facts and theory ${ }^{[20]}$.

Looking at the domestic scholars' study on the research object of geography of education, although the number of studies is small, it shows that domestic scholars attach importance to the research object of geography of education. As Selected Works of Mao Zedong - Volume I elaborated on the research object from the perspective of Marxist philosophy, he wrote that: "The distinction of scientific research is based on the special contradictions possessed by scientific objects. Therefore, the study of a contradiction peculiar to a field of a certain phenomenon constitutes the object of a certain subject." On the other hand, it also shows that geography of education is indeed a discipline with a relatively lighter age and absolute age. Because the research object is clear determines its level of development and maturity, as well as its scientific content.

\section{Foreign scholars' different comprehension on research object of geography of education}

Most of the foreign scholars' study on the research object of geography of education is not as specific as domestic scholars, but they are comprehensively discussed with the concept, discipline system and development process of geography of education. Education is a central institution. The study of geography of education is the application of geographic analysis to conduct observable behavioral research on educational space and landscape at different scales (countries, regions, communities, schools) ${ }^{[21]}$. Elsen pointed out in the article Geography of education that geography of education should mainly study the education conditions on the Earth's surface in relation to any part of education. This kind of education environment mainly includes the type of education conditions 
in any area or area where people live with education characteristics. At the same time, Elsen also pointed out that in a broad sense, education in geography of education should include formal education and non-formal education. In other words, "education" includes both school education and non-formal educational organizations formed by communities, libraries, churches, and other organizations in areas where there are no schools ${ }^{[22]}$. Geography of education is the study of the spatial pattern of educational phenomena. Geographical research on educational phenomena is not only a static nature, but also a theoretical field for predicting or hypothesizing whether educational phenomena exist or are closely related to past educational phenomena. The main theme is the study of the geography of the dynamic development of educational phenomena. At the same time, Ryba also discussed three aspects: 1) Geographical examination of the potential factors of education; 2) Investigation of the spatial pattern of educational phenomena; 3 ) The role of education as a factor influencing the geographical structure and other socio-cultural phenomena.

In his article Why Didn't Have an Educational Geography? published in the geographical magazine, Gerald $\mathrm{H}$. Hones clearly stated that educational geography should apply geographical science and technology to solve a variety of educational issues ${ }^{[23]}$. In other words, the research object of educational geography is all educational issues that can be solved by geographical techniques, such as the delineation of school district boundaries, regional variables related to educational opportunities and school supply and the spatial distribution pattern of educational institutions. From a macro perspective, educational geography can also use maps to express and analyze educational data on a global scale. Taylor also elaborated on the research objects of educational geography in Towards Educational Geography. He believes that the research object of educational geography is the education space, place and time concept in different regions and all education issues affected by geographical factors. Taylor places great emphasis on spatial and local research in educational geography and emphasizes the use of electronic maps to help researchers understand space and place, as well as spatial analysis and spatial statistics ${ }^{[24]}$, such as network analysis, space-time analysis, multi-level modelling and geographically-weighted statistical analyses. Locations in geography represented an eternal theme, for example, the United States Joint Commission for Geography Education identified "positions" as one of the five themes in geography. Educational geography emphasizes the value of a cultural approach, exploring the different manifestations of education through different spaces ${ }^{[25]}$. It is an exploration of all educational phenomena that affect education supply, consumption and education as spatial variables change. In the study of educational geography, the spatial production, consumption, and enlightenment of families, neighborhoods, community organizations, and community work areas in the formal education system from kindergarten to higher education and non-formal education should primarily be considered $^{[6]}$.

From the research of foreign scholars on the object of geography of education research, it can be seen that the research object of geography of education is mainly the "educational phenomenon", "educational environment" and "educational problem" affected by space. Different scholars have different opinions, but most scholars emphasize the importance of "space", "time" and "scale" in this discipline, especially when establishing the object of geography of education research.

\section{Research object of geography of education - educational geographic complex}

With the rapid development of human science and technology, there is almost no pure natural environment on the Earth that is not affected by human activities. The natural world as a human living environment has become a socialized natural world. In the humanized nature, the geographical environment of geography research is not limited to a narrow natural environment, but is a generalized geographical environment composed of inorganic, organic and social elements. 
With the rise of the quantitative revolution in academic geography in the 1950s, the emphasis on localities and regions was gradually separated from the spatial analysis of universities and schools ${ }^{[26]}$.Geography comprehensively studies its entirety which is called a regional complex of geographical environments. Geography analyzes and studies the interrelationships among the various elements within the regional complex, its structure and the laws of regional differentiation. The research object of geography science is the Earth surface terrestrial space system. In the specific study, Pan Yujun divided the Earth surface terrestrial space system into regions (areas, territories) of different scales, and they have become a number of specific research objects of geography science. Since one of the theoretical foundations of geography of education is geography, if the study of education is separated from "geography", it will no longer be the content studied in geography of education. Therefore, the overall logic of geography of education research object is from geography research object to geography of education research object. According to such a logical path, the research object of geography of education is the Earth's surface education space system. The "people" who is the subject of educational activities in the education complex has initiative, and it is similar to the "people" in the relationship between man and land. The survival and development of education depends on a certain material basis and space. Because the Earth land surface education spatial system is affected by many different factors, and it is divided into regions (areas) of different scales. Each region and its counterpart also have educational geographical objects in this region. As the object of geography of education, the "Earth land surface spatial system" is related to "region", and therefore, a more concrete concept can be condensededucational geographic complex.

In a broad sense, the educational geographic complex mainly refers to the integration of "people" in the education within a certain territory (area, region) and the geographical environment that they rely on in different periods. The so-called "place" refers to the integration of natural and human elements in accordance with certain rules, which form a close integration of the geographical environment as a whole. The narrowly defined educational geographic complex refers only to the education of a regional system within a certain period of time. In other words, it can refer to education in a region with a certain spatial distribution and spatial distribution. The "people" in the generalized educational geographic complex mainly refers to all people related to educational activities, including students, teachers, education administrators and student parents. The "place" in the educational regional complex includes both the natural environment and the human environment. The former includes natural geographical elements such as land forms, climate, hydrology and soil, while the latter includes geographical elements such as agriculture, industry, minerals, economy and transportation. Education is historic (that is, the temporal past), and it is also spatial. Time is the space for human development, and space can be transformed into time. The two are closely linked.

\subsection{Spatial structure of educational geographic complex}

Social theories are increasingly concerned with the analysis of spatial issues, recognizing that space has been theorized and the relationship emphasizes marginalization of modernism of time and history ${ }^{[27]}$. Education researchers began to think about space in the mid-1990s, and Michael Peters was the first person to do so . Taking the concept of geography as space science is extremely important in the history of geology ${ }^{[28]}$, which can be formed immediately after the formal expression of a space-time language. Formal abstract language enables geographers to occupy a high level of his own cultural background to study spatial forms and processes in different cultural complexes. Therefore, geography is the study of spatial forms and structures that were formed in history and defined by the mode of production ${ }^{[29]}$. The holistic nature of the geographical environment not only has elemental meaning, but also has geographical meaning. Because of the 
spatial relationship of educational geographic complexes in space, the degree of agglomeration, and the direction and intensity of the interactions that occur through linear infrastructure, the spatial structure includes the element structure and regional structure of educational geographic complexes.

The spatial element structure of educational geographic complex: The elemental structure of educational geographic complex mainly refers to the complicated educational spatial structure that interacts and restricts each other through the flow of energy, material flow and information flow. The essence of synergy between geography of education, comparative education and international education is "information flow". Information flow is not just a direct transfer of knowledge from school to the network through educational activities. It can also be formed through human migration. The flow of information is spatially dynamic. The "information flow" flows from the center point (area) to the surrounding area ${ }^{[30]}$, regroups in different directions and distances from the center, and combines with the original natural and socio-economic elements of the area to form new ones.

The spatial structure theory aims to study the spatial combination, correlation and evolution of various elements within the system. The spatial element structure of educational geographic complex is made up of the interaction and coordination of information flow of "points" such as schools, families and community organizations and educational institutions (including both formal and non-formal education), "lines" formed by the network that has a certain impact on education and "surfaces" formed by villages, towns (townships), cities (counties) and states. The "points" consist of educators, educators, educational administrators and the "minimal scale" environment within the nodes (which can be understood as all educational facilities), the "lines" are mainly composed of transportation networks and wireless networks, while "surfaces" consist of all natural and human environments of different scales. Therefore, the educational geographic complex is composed of various elements that are harmonious and organic. It is neither a disorganized, nor a simple superposition of various elements. Each element cannot exist in isolation.

The regional spatial structure of educational geographic complex: Geography is a science about geographical differentiation, and the region is a concrete embodiment of the integration of natural and human phenomena. In the book Introduction to Geographical Sciences, Professor Pan classifies the geographical structure as background areas, relevant areas and secondary areas. Because the natural differentiation law leads to great differences in the population, economy, and education level of different regions (areas), the regional spatial structure of the educational geographic complex can be expressed as the background areas, relevant areas and secondary areas of the educational geographic complex. They will of course change accordingly with the changes in the geographical structure studied by the researchers. The background area of the educational geographic complex is the basis for the study of relevant areas and secondary areas. If the characteristics and the objective reality of the background area are not taken into consideration, the research on the relevant areas and secondary areas is isolated and one-sided. The study of relevant areas in education plays an important role in regional research, while that of secondary areas complements it. Therefore, the study of geographical elements of educational geographic complex is interrelated and mutually influenced. For example, when the educational phenomenon or education problem studied by the researcher is based on the "state domain", then the background area should be the whole country, the relevant area is the other state area other than its main research area, and the secondary area is the city area included in the studied state. Because different regions have different characteristics, resources (type, composition, quantity, quality, etc.) and conditions (natural and socio-economic conditions), and development potentials and possibilities are different from each other. The problems are not the same. The spatial structure of educational complexes is very different. Only by observing the differences and finding the influencing factors of differences, can the research of the educational geographic complex be integrated and connected rather than an isolated study, and the results of the research can be clearer and more valuable. 


\subsection{Time structure of educational geographic complex}

Time and space constitute the social structure ${ }^{[31]}$. Different societies produce different concepts of space and time. If geography is separated from "history", it is like the car has no power. It is imperative to study the basic spatio-temporal relationship as a key background in education ${ }^{[14]}$. In addition to studying the spatial structure, the educational geographic complex needs to be studied from the time structure. Education has a long history of development. The education process is also a process of slow knowledge transfer and acquisition. Another factor that has to be taken into account when studying educational geographic complex is the time structure of educational territories. The time structure of the educational geographic complex can be summarized as a "past", a "current" and a "future" educational geographic complex. A detailed study of the "past" educational geographic complex aims to use the "past" experience and lessons to guide the "current" educational geographic complex and predict "future" educational geographic complex. The process of change in the educational geographic complex is objective. People cannot ignore their objective facts and subjectively criticize. An in-depth study of their course of change is also a task of time series. In the empirical study of educational regional complexes, it is very important to study the number of educational geographical objects or educational geographical phenomena. At the same time, according to the actual situation in many aspects, choose a certain amount of time and size to study the time series of educational regional complexes in different regions (areas) or choose the same time scale to conduct a comparative study of the educational geographic complex in different regions. For example, by collecting a large number of provincial compulsory education data to conduct quantitative (cluster analysis, regression analysis) research on Chinese provincial compulsory education in a certain historical time period, we can find the influencing factors of the temporal and spatial structure changes, the balanced development early warning and countermeasures system of China's compulsory education.

\section{Conclusion and recommendation}

In recent years, the study of geography of education has shown a vigorous momentum. More and more scholars have realized that geographical factors have different effects on education. It is undeniable that everything in the world cannot exist independently from geographical factors, and education is affected by many geographical factors. Following the principle and theories of spatial scale conversion, educational phenomena at different spatial scales have certain differences. As one of the important cultural things, education has distinct spatial attributes. It determines that we should study, explore, reveal and clarify the geospatial laws of education and develop geography of education from the perspective of geography. Geography of education studies all geographically influenced educational territories on the surface of the Earth. In other words, geography of education studies different areas or regions on the Earth's surface (relevant areas and secondary areas) based on general characteristics (e.g., background regions). It is necessary to study the degree and factors of education influenced by geographical laws and things, and to study specific educational geographical phenomena and problems. At the same time, geography of education is the science of studying regional differences in education.

The reason why geography of education should have a unique research object is that its "uniqueness" lies in the applicaion of time and space to study education. The unique research object of geography of education indicates that geography of education is thriving as an independent discipline. Scholars at home and abroad also attach great importance to the research of geography of education. Whether the research object of geography of education is clear or not directly determines the development level and maturity, as well as its scientific content of this discipline. Most scholars emphasize that in determining the research object of geography of education, we must consider 
issues from different perspectives such as "space", "time" and "scale", because the concept of time and space is closely related to the human understanding of the entire world. It is not only the object of philosophical research, but also an important part of scientific research in various natural sciences and humanities.

This article only recognizes geography of education from the perspective of geography of education. However, there is much room for research and exploration in the discipline of geography of education. For example, in the field of theoretical research, there are researches on educational geographic ontology, epistemology, methodology and knowledge theory, as well as on research methods, research cores, disciplinary systems and other important categories. In applied research, there are mainly applied spatial analysis methods for various educational phenomena and educational issues, educational atlas research, spatial distribution of educational resources and educational opportunities, comparative studies of regional educational structures, school site selection or spatial layout studies, etc. At the same time, after establishing the research object of geography of education, multiple research methods such as geography, education and demography should be comprehensively applied to follow the "heaven and logical unity" from the perspective of its history and logic. Following the research approach of "comprehensive integration from qualitative to quantitative”, empirical geographical research methods such as geographical research method, data analysis method, comparison method, map analysis method, geographical model method, geographical division method, SWOT analysis method, index method and induction method and scenario analysis method are mainly used to conduct geography of education research.

\section{Acknowledgements}

The support from the National Natural Science Foundation of China (41671148) and the China Scholarship Council (201708535062) is gratefully acknowleged.

\section{References}

[1] Tuck J P. The Study of Education: A Collection of Inaugural Lectures. British Journal of Educational Studies, 29,3(1981)

[2] Pan Yujun, Luo Si yuan, \&Duan Yong. Basic research on geography: foundamental value of geography. Journal of Yunnan Normal University Natural Sciences Edition), 22(5), 50-54(2002)

[3] Brock, C.The geography of education and comparative education. Comparative Education, 49(3), 275-289(2013)

[4] Thiem, C. H.Thinking through education: the geographies of contemporary educational restructuring. Progress in Human Geography,33(2), 154-173(2009)

[5] Johanna Waters, \& Rachel Brooks. International/transnational spaces of education. Globalisation Societies \& Education, volume 9(9), 155-160(2011)

[6] Holloway, S. L., \& Jöns, H. Geographies of education and learning. Transactions of the Institute of British Geographers, 37(4), 482-488(2012)

[7] Luo Mingdong. Geography of education. Kunming:Yunnan University press(2012)

[8] Mitchell, K. Educating the national citizen in neoliberal times: from the multicultural self to the strategic cosmopolitan. Transactions Of The Institute Of British Geographers, 28(4), 387-403(2003)

[9] Lewis, $N$. Code of practice for the pastoral care of international students: making a globalising industry in new zealand. Globalisation Societies \& Education, 3(1), 5-47(2005)

[10] Waters, J. L. Emergent geographies of international education and social exclusion. Antipode, 38(5),10461068(2006)

[11] Lu Dadao. The value of geographical science and the feelings of geographers. Acta Geographica Sinica, 70(10), 1539-1551(2015)

[12] Mills, S., \& Kraftl, P. Informal education, childhood and youth. Children S Geographies, 14(5), 1-2(2016)

[13] Bednarz, S. W. Review of geography of education: scale, space and location in the study of education. London: Bloomsbury Academic,(2017)

[14] Brock, C., \& Alexiadou, N. Education Around the World: A Comparative Introduction,(2013) 
[15] Luo Mingdong. On the Geography of Education. Journal of Yunnan Normal University (Natural Sciences Edition)(2), 95-102(1998)

[16] Pan Yujun, \& Wu Youde. Introduction of Geographical Sciences. Beijing:Beijng Science Press(2014)

[17] Yi Ji-dong, \& Yao Hui. Objects and Contents of the Geography of Education. Journal of Yunnan Normal University (Philosophy and Social Sciences Edition) , 44(2), 9-10(2012)

[18] Zhang Dongfen. Study On Chinese Educational Geography. Journal of Hengyang Normal University (3), 131136(2000)

[19] Shang Zhi-hai. Study Educational Geography Bassd On Developing Trend Of Geography. Yunnan Geographic Environment Research, 20(5), 121-125(2008)

[20] Qian Chunfu. Nature and Value of Educational Geography as an Academic Discipline-Reflections Triggered by Reading Educational Geography by Prof. Luo Mingdong.Journal of chuxiong normal university, 29(7), 68-73(2014)

[21] McCreary, T., Basu, R., \& Godlewska, A. Critical Geographies of Education: Introduction to the Special Issue. Canadian Geographer, 57(3), 255-259(2013)

[22] Butler, T., \& Hamnett, C. The Geography of Education: Introduction. Urban Studies (Routledge), 44(7), 11611174(2007)

[23] Gerald H. Hones, Raymond H. Ryba. Why Not a Geography of Education?. Journal of Geography, 71(3):135139(1972)

[24] Taylor, C. Towards a geography of education. Oxford Review Of Education, 35(5), 651-669(2009)

[25] Mills, \& Sarah. Geographies of education, volunteering and the lifecourse: the woodcraft folk in britain (19251975). Sage Publications(2016)

[26] Conolly, G. Geography in british schools 1850-2000. Geographical Education, 15(2002)

[27] Robin Usher. Putting space back on the map: globalisation, place and identity. Educational Philosophy \& Theory, 34(1), 41-55(2002)

[28] Hartshorne, $R$. The concept of geography as a science of space, from kant and humboldt to hettner. Annals of the Association of American Geographers, 48(2), 97-108(1958)

[29] Dunford, M. Historical materialism and geography. Relevé Épidémiologique Hebdomadaire, 70(30), 217218(1981)

[30] Arreola, D. D. Spencer, j.e. and thomas, w.l. jr 1969: cultural geography: an evolution,ary introduction to our humanized earth. new york: wiley. Progress in Human Geography, 30(5),(2006) [31] Mechtraud, \& Schnepp, G. J. The Elementary Forms of the Religious Life. American Catholic Sociological Review, 16(3), 228(1955) 